\title{
Indentification of cancer stem-like cells in osteosarcoma and their implications in response to chemotherapy
}

\author{
Áurio O Lopes ${ }^{1 *}$, Sara R Neves, Anália do Carmo², Artur A Paiva ${ }^{3}$, Maria Botelho ${ }^{1}$, Célia M Gomes ${ }^{1}$ \\ From 16th International Charles Heidelberger Symposium on Cancer Research \\ Coimbra, Portugal. 26-28 September 2010
}

\begin{abstract}
Aim
There are growing evidences that tumors contain a subset of cells with stem like properties. These cells are referred as cancer stem cells (CSC) and are responsible for driving tumor growth and recurrence. We aimed to isolate and characterize putative CSCs in a human osteosarcoma cell line (MNNG/HOS) and to explore their role in response to chemotherapy.
\end{abstract}

\section{Methods}

CSCs were isolated using the sphere-forming assay in serum-free medium under non-adherent conditions and characterized for the expression of mesenchymal stem cell markers $\left(\mathrm{CD} 90^{+}, \mathrm{CD} 105^{+}, \mathrm{CD}^{+} 3^{+}\right)$by flow cytometry. The chemosensitity of MNNG and CSCs to doxorubicin (DOX), cisplatin (CIS) and methotrexate (MTX) was evaluated using the MTT colorimetric assay after an incubation period of $48 \mathrm{~h}$. Cell cycle progression was analyzed by flow cytometry with propidiun iodide.

\section{Results}

A subpopulation of tumor cells formed sphere-clusters in serum-free medium and were positive for MSC markers. These cells revealed to be more resistant to chemotherapy in comparison with MNNG/HOS cells. The half maximal inhibitory concentrations $\left(\mathrm{IC}_{50}\right)$ of DOX $(0.66 \pm 0.24 \mu \mathrm{M})$, CIS $(13.18 \pm 0.09 \mu \mathrm{M})$ and MTX $(0.05 \pm 0.01 \mu \mathrm{M})$ were significantly higher $(\mathrm{p}<0.05)$ than those in MNNG/HOS cells (DOX: $0.30 \pm 0.07 \mu \mathrm{M}$; CIS: $8.08 \pm 3.78 \mu \mathrm{M}$; MTX: $0.006 \pm 0.001 \mu \mathrm{M}$ ). All drugs induced a G2/M cell cycle arrest in MNNG/HOS

\footnotetext{
* Correspondence: olopes10@hotmail.com

${ }^{1}$ Institute of Biophysics and Biomathematics - IBILI - FMUC, Coimbra, Portugal

Full list of author information is available at the end of the article
}

cells. In opposite, no significant changes were observed in CSC.

\section{Conclusions}

We have identified a subset of tumor cells with stemlike properties in OS that are relatively resistant to conventional chemotherapeutic agents. Therefore conventional drugs might not address this subset of cells that can be responsible for tumor regrowth after therapy.

\section{Author details}

${ }^{1}$ Institute of Biophysics and Biomathematics - IBILI - FMUC, Coimbra, Portugal. ${ }^{2}$ Center for Neurosciences and Cell Biology, Coimbra, Portugal. ${ }^{3}$ Histocompatibility Centre of Coimbra - University Hospital of Coimbra, Coimbra, Portugal.

\section{Published: 24 September 2010}

\section{doi:}

Cite this article as: Lopes et al:: Indentification of cancer stem-like cells in osteosarcoma and their implications in response to chemotherapy. BMC Proceedings 2010 4(Suppl 2):P41.

Submit your next manuscript to BioMed Central and take full advantage of:

- Convenient online submission

- Thorough peer review

- No space constraints or color figure charges

- Immediate publication on acceptance

- Inclusion in PubMed, CAS, Scopus and Google Scholar

- Research which is freely available for redistribution

Submit your manuscript at www.biomedcentral.com/submit
C Biomed Central 